\title{
Urgences
}

\section{Sur le mur noir...}

\section{Louise Dupré}

Numéro 15, octobre 1986

Épigraphiques

URI : https://id.erudit.org/iderudit/025292ar

DOI : https://doi.org/10.7202/025292ar

Aller au sommaire du numéro

Éditeur(s)

Urgences

\section{ISSN}

0226-9554 (imprimé)

1927-3924 (numérique)

Découvrir la revue

Citer ce document

Dupré, L. (1986). Sur le mur noir... Urgences, (15), 24-24.

https://doi.org/10.7202/025292ar

Ce document est protégé par la loi sur le droit d'auteur. L'utilisation des services d'Érudit (y compris la reproduction) est assujettie à sa politique d'utilisation que vous pouvez consulter en ligne.

https://apropos.erudit.org/fr/usagers/politique-dutilisation/
Cet article est diffusé et préservé par Érudit.

Érudit est un consortium interuniversitaire sans but lucratif composé de l’Université de Montréal, l'Université Laval et l'Université du Québec à Montréal. Il a pour mission la promotion et la valorisation de la recherche. https://www.erudit.org/fr/ 


\section{Louise Dupré}

Il aurait voulu ne pas avoir eu d'enfance.

Hugues Corriveau: Scènes

Sur le mur noir, il voit, immobile, la catastrophe. Il plisse les paupières et voit. Il ne dort pas. Pas de sommeil possible même si on lui a dit: "Dors". Il a vu, sans épaisseur, la catastrophe, il regarde maintenant cette chambre habitée. Il n'a pas peur. Il ne souffre pas. Il reste là à attendre que quelque chose se produise, que la nuit recommence la nuit. Il sait que cela n'arrivera pas. Que cela ne se peut pas. Il attend sans attendre. Il reste là, petit et tranquille, dans la vision qu'il a pour toujours de la catastrophe. Il regarde. Peu à peu le mur. Les fissures noires du mur qui s'écartent jusqu'à s'ouvrir. C'est par là, par là qu'elle se glisse dans la chambre et s'imprime sur le noir. Il ne dort pas. Ne peut pas dormir. Quelque chose se prépare, tragique, un commencement, il ne sait pas comment il sait, il attend de l'apprendre, du fond de lui-même, de l'inarticulation de son savoir. Demain on s'inquiétera de sa pâleur, de ses cernes sous les yeux. Demain il devra sourire et rassurer. Il voit. Il regarde, brillante, la catastrophe. Il se colle contre le dos moite de sa soeur. Il ne dort pas. Il sait qu'il ne dormira pas. Il attend. 